\section{The study of asymptomatic Plasmodium falciparum in humans infectedwith immunodeficiency virus in Ile-Ife, Nigeria}

\author{
Olarinde Olaniran,,$^{1,2}$ \\ Olusola Ojurongbe, ${ }^{3}$ \\ Rachel Edoghogho Hassan-Olajokun, ${ }^{1}$ \\ Akeem Abiodun Akindele, 4 \\ Margaret Oluwatoyin Japhet, 5 \\ Samuel Oloyede Bolaji, ${ }^{3}$ \\ Adeyinka Adedokun ${ }^{4}$ \\ 'Department of Medical Microbiology \& \\ Parasitology, Obafemi Awolowo \\ University Ile-Ife; ${ }^{2}$ Department of \\ Nursing, Obafemi Awolowo University \\ Teaching Hospital Complex, Ile-Ife; \\ ${ }^{3}$ Department of Medical Microbiology \& \\ Parasitology, Ladoke Akintola University \\ of Technology, CHS, Osogbo; \\ ${ }^{4}$ Department of Community Medicine, \\ Ladoke Akintola University of \\ Technology, CHS, Osogbo; ${ }^{5}$ Department \\ of Microbiology, Obafemi Awolowo \\ University, Ile-Ife, Nigeria
}

\section{Abstract}

The study of the prevalence of asymptomatic Plasmodium falciparum in humans infected with immunodeficiency virus (HIV) was carried out in Ile-Ife, Osun State Nigeria. The aim of the study is to determine the prevalence of asymptomatic infection $P$. falciparum in HIV positive individuals and correlate it to age Parasitaemia and CD4 T cell count. Out of ninety three (93) HIV positive patients that participated in the study, 53 (58.8\%) were females while 40 (41.4\%) were males; 48 (52.4\%) females and 35 (33.8\%) males were positive for asymptomatic $P$. falciparum given a total number of 83 (86.6\%). Twenty non-HIV patients were used as control samples: 9 (45\%) were males and 11 (55\%) were females. With 3.0 (33.3\%) males and 5 (45.45\%) females were positive with insignificant value of mean Parasitaemia of $125.0 \mu \mathrm{L}$ of blood. Age group 31-40 had the highest positive rate of 26 (32.2\%) and age group 11-20 and above 60 had the least of positive rate. The correlation between age and both CD4 T cell count and Parasitaemia showed levels of significance less than $0.01(\mathrm{P}<0.01)$ while the correlation between CD4 T cell and count and Parasitaemia showed no significant correlation, having $P$-value of $P>0.05$. Comparing the males mean age, CD4 $\mathrm{T}$ cell count and Parasitaemia with that of females there was no level of significance P-value being greater than $0.05(\mathrm{P}>0.05)$ each. In conclusion, the study showed that in asymptomatic Plasmodium falciparum, almost all the tested samples were positive which could be as a result of depletion in the immune level, hence there is need to always screen for Plasmodium falciparum whether in asymptomatic or symptomatic patients. The CD4 T cells count from the study can not be used for the detection or determination of the presence of malaria infection in HIV positive patients. The best method for malaria identification so far is still the staining method. There should not be discrimination when sampling the patient when investigations on HIV and malaria are to be carried out when both are infected.

\section{Introduction}

Malaria is a tropical, vector borne infectious disease caused by protozoan parasites of the genus Plasmodium and carried by infected mosquitoes of the genus Anopheles. Malaria has infected humans for over 50,000 years, and may have been a human pathogen for the entire history of our life. ${ }^{1-4}$ There are four species of malaria affecting humans: they are i) Plasmodium falciparum which causes malignant tertian malaria, ii) Plasmodum vivax which causes benign tertian malaria; iii) Plasmodium ovale which causes tertian malaria and iv) Plasmodium malariae which is responsible for quartan malaria. The classical symptom of malaria is cyclical occurrence of sudden coldness followed by rigor and then fever and sweating lasting four to six hours, this occurs every two days in $P$. vivax and $P$. ovale infections, while every 3 days for $P$. malariae. Sign and symptoms are caused by the presence of the erythrocytic stages of the parasite in the red blood cells. In the Plasmodium falciparum malaria, only the blood-forms of the parasite exist. There is an additional persistent infection in the liver (the extra- erythrocytic form) in all other forms of malaria and it is the factor responsible for relapses. The clinical picture is one of recurring rigors, anaemia, toxaemia and splenomegaly. ${ }^{5-6}$

Malaria is widespread in tropical and subtropical regions, including parts of the Americas, Asia, and Africa. ${ }^{1}$ Each year, it causes disease in approximately 515 million people and kills between one and three million people, the majority of whom are young children in Sub-Saharan Africa. ${ }^{1}$ An estimated 280 million people are carrier of the malarial parasites in the region. In Nigeria, malaria has a high morbidity and mortality rate in children and pregnant women. ${ }^{7-9}$

Malaria caused by Plasmodium falciparum
Correspondence: Olaniran Olarinde, Department of Medical Microbiology and Parasitology OAU Ile-Ife, Nigeria.

E-mail: olarinde.olaniran@yahoo.com

Key words: prevalence, HIV, Plasmodium falciparum.

Received for publication: 7 September 2011. Revision received: 31 October 2011.

Accepted for publication: 2 November 2011.

This work is licensed under a Creative Commons Attribution NonCommercial 3.0 License (CC BYNC 3.0).

(C) Copyright O. Olaniran et al., 2012

Licensee PAGEPress, Italy

Microbiology Research 2012; 3:e1

doi:10.4081/mr.2012.e1

is the major public health problem in the tropics in patient with HIV infection. In nonimmune subjects for instance (HIV subject), infection with a Plasmodium falciparum at any age leads to clinical diseases associated with a high case fatality rate if untreated. ${ }^{10-11}$

Malaria is an important disease in the tropics. It results in more than a million deaths out of the 300 million cases recorded annually. Around $90 \%$ of these deaths occur in Africa, mostly in young children. Malaria is Africa's leading cause of mortality in children less than 5 years (20\%) and constitutes $10 \%$ of the continent's overall disease burden. It accounts for $40 \%$ of public health expenditure, $30-50 \%$ of impatient admissions, and up to $50 \%$ of outpatient visits in areas with high malaria transmission. Over the years it has been found that malaria infection has more effects than its acute consequences. The role of malaria as a predisposing factors or significant co-morbidity has been documented in HIV infection, tuberculosis and in pregnancy. ${ }^{12-14}$ In those infected with HIV, susceptibility to malaria and parasitaemia increase as immune response fails. Clinical malaria is more common, particularly in less immune people. Acute falciparum malaria is thought to increase HIV replication with possible disease progression and increased risk of mother to child transmission of HIV. ${ }^{15-17}$ The present study therefore is to determine the prevalence of malaria parasite (Plasmodium falciparum) in asymptomatic HIV positive patients, analyse the association between age and Parasitaemia, test the relationship between age and CD4T cells count and to analyze the relationship between age, CD4T cells count and Parasitaemia. 


\section{Materials and Methods}

\section{Location of study}

The study was carried out at the Ife Hospital Unit of Obafemi Awolowo University Teaching Hospital Complex (OAUTHC) Osun State, Nigeria from June 2008 to December 2008. Participants were HIV positive patients attending the Haematology/Serology Clinic. Non-HIV individuals without symptoms of malaria were used as control.

\section{Subject selection}

Individuals positive for HIV but without symptoms suggestive of malaria were recruited. A total of 93 HIV positive patients and 20 Non-HIV individuals without symptoms suggestive of malaria were all recruited into the study.

\section{Collection of specimen}

Whole venous blood from the 93 patients and 20 control individuals were collected into commercially prepared EDTA tubes and labeled accordingly. These were later transported to Department of Medical Microbiology and Parasitology, Faculty of Basic Medical Science, Obafemi Awolowo University, Ile-Ife, for parasitological investigation.

\section{Laboratory processing of samples}

The blood samples were taken to the laboratory for both microscopic and serological analysis (CD4T cells count).

\section{Microcopic examination}

The thin films were fixed with methanol and all films were stained with $3 \%$ Giemsa stain of pH 7.0 for $30 \mathrm{~min}$ as recommended by WHO. Taking the number of leucocytes per micro liter of blood as 8,000, parasite density of blood using the thick film was expressed as: parasite count $(x) 8,000$ divided by number of WBCs counted. The thick films were used to determine the parasite densities while thin films were used to identify the parasite species and infective stages. Stained slides were examined under the light microscope using $\times 100$ objective lens (immersion oil). Number of parasite counted $(\times 8000 / \mathrm{cmm}) /$ number of WBC counted: WHO standard for $\mathrm{WBC}=6000-8000 / \mathrm{cmm}$ normal. ${ }^{15}$

\section{Estimation of the CD4T cell counts}

The estimation of the CD4 cells count for the 93 samples used in this study was done using a two-colour single platform flow Ctytometer (Cytoflow partec). It was carried out at HIV unit of the Department of Haematology and Blood transfusion, OAUTHC, Ile-Ife, Osun State.

\section{Results}

A total of ninety three (93) patients participated in the study out of which 53 (58.6\%) with mean age 31.62 years, Parasitaemia 1861 per $\mu \mathrm{L}$ of blood and CD4 T cells count of 424.83 cells for the female and 40 (41.4\%) males with mean age 29.62 years, parasitaemia 1570.00 per $\mu \mathrm{l}$ of blood and CD4 T cells count of 486.43 cell. Forty-eight (52.4\%) female were positive with mean age of 31.25 years while only 5 (6.2\%) with mean age of 35.20 years were negative; $35(33.8 \%)$ of the male were positive with mean age 27.60 years while 5 (7.7\%) with mean age of 43.80 years were negative.

In summary, the total number positive samples in the study was $83(86.2 \%)$ with mean age of 29.71 years while 10 (13.8\%) with mean age of 39.50 years were negative for malarial infection. Age group 31-40 years had the highest number of positive samples 26 (32.2\%) with mean age of 35.42 years, CD4 T cells count of 807.24 cells and Parasitaemia $2,938.82$ per $\mu \mathrm{L}$ of blood. This was followed by age group 21-30 years 20 (19.6\%) with mean age of 28.10 years, CD4 count 325.55 cells and Parasitaemia 1698.00 per $\mu \mathrm{L}$ of blood. Age group 0-10 years; 18 (1.9\%) with mean age of 3.18 years, CD4T count 807.24 cell, and Parasitaemia 2938.82 per $\mu \mathrm{L}$ of blood. Age group 41-50 years [14 (22.2\%)] with mean age 45.29 years, CD4T count 354.64 cells and Parasitaemia of $1862.86 \mathrm{l}$ per $\mu \mathrm{L}$ of blood and age group 11-20 years and 60 years had the least number of positive sample of $1(0.6 \%)$ and $1(2.1 \%)$ with mean age, CD4 T cells count and Parasitaemia of 16.00 years, 381.00 cell, 160.00 per $\mu \mathrm{L}$ of blood and 61.00 years, 1154.00 cell, 1600.00 per $\mu \mathrm{L}$ of blood. Using infection state of CD4 count Group (normal value $\geq 350$ CD4 T cells count). Out of 44 (51.2\%) of the samples that have CD4 T cells less than 350,39 (44.0\%) were positive for malaria with the mean age of 32.31 years, CD4 T cells count 176.6 9cells and Parasitaemia of 1877.95 per $\mu \mathrm{l}$ of blood. The CD4 T cells count group that has greater than 350 are 49 (48.8\%) out of which $44(42.2 \%)$ were positive with age 27.41 years, CD4 T cells count 698.91cells and Parasitaemia of 2005.45 per $\mu \mathrm{L}$ of blood. A Total of twenty asymptomatic HIV negative samples were used as control. Nine (45\%) with mean age 27.78 years, parasitaemia $40.00 \mu \mathrm{L}$ and CD4 T cells count of 493.11 cell are for males, while 11 (55\%) with mean age 38.27 years, parasitaemia 58.18 per $\mu \mathrm{L}$ of blood and CD4 T cells count of 540.09 cells are for females. Twelve (60\%), with 6.0 males with mean age 30.00 years, Parasitaemia 0.000 per $\mu \mathrm{L}$ of blood and CD4 T cells counts of 365.83 cells and 6.0 females with mean age of 39.50 years, parasitaemia 0.000 per $\mu \mathrm{L}$ of blood and CD4 T cells count of 469.83 cells were negative. Eight
(40\%) out of which 3 (33.33\%) males with mean age of 23.33 years, CD4 T cells count of 747.67 cells and Parasitaemia of 120.00 per $\mu \mathrm{l}$ of blood and 5 (45.45\%) females having 36.80 years, CD4 T cells count of 624.40 cells, Parasitaemia of 128.00 per $\mu \mathrm{l}$ of blood were all positive (Tables 1-3).

\section{Discussion}

The study showed that there is a high prevalence of asymptomatic Plasmodium falciparum in the HIV patient samples used. 83 (86.2\%) out of 93 HIV samples were positive for $P$. falciparum with females having the highest of 48 (52.4\%) compared to the males with 35 (33.8\%). The assessment of the effect of Plasmodium falciparum malaria on concentrated HIV in blood by Kublin et al. ${ }^{18}$ support the results above; out of 367 HIV patient recruited 334 people were parasitaemic at baseline and 148 had at least one malaria episode during follow-up and received antimalarial treatment. The work done by Onyenekwe et al., ${ }^{19}$ also agreed with the high prevalence of malaria in HIV patients with 12 (11.8\%) of the 16 (33.3\%) total HIV positive group used. In this study, Malaria parasites were observed in 8 of the HIV negative control samples. The differences in the prevalence rate between the HIV positive group and the control HIV negative confirms the high prevalence of malaria parasites in HIV positive compare to non HIV patients. Considering the CD4 $\mathrm{T}$ cell count which for a normal individual should be greater or equal to $350(\geq 350)$. In this study, out of 44 (51.2\%), 39 (44.0\%) were positive for malaria parasites with lower CD4Tcellcount and 44 (42.2\%) out of 49 (48.8\%) of the CD4 T cell count greater or equal to 350 had higher prevalence of asymptomatic Plasmodium falciparum malaria. Looking at the correlation table there was no level of significance between the CD4Tcell count and Parasitaemia, showing that decrease or increase in CD4T cell count did not have implication on the increase or decrease of Parasitaemia in asymptomatic malarial infection, this is supported by the work of French et al. ${ }^{20}$ on the investigation on the effect of HIV -associated immune suppression on malaria fever rate carried out in Uganda which stated that the data they had only supported an interaction between symptomatic Plasmodium falciparum and HIV and did not support any interaction in asymptomatic $P$. faciparum Parasitaemia and HIV. Almost all CD4T cells count was above 350 cells except three samples having mean CD4 Tcells count of 236.3 cells. There was a correlation between the age and the CD4 Tcell count and parasitaemia according to the data recorded in the 
study, with the level of significance found to be less than $0.01(\mathrm{P}<0.01)$ which is significant for both. As the age increased, parasitaemia decreased and also as the age increased the CD4 $\mathrm{T}$ cell count also increased. This is in agreement with the work done in a village community in northern Nigeria by Engelbrecht et $a l .{ }^{21}$ The age distribution of the average number of parasite clones present in $P$. falciparum infections showed an initial increase, then reached peak multiplicity in children 8-10 years of age, and afterwards decreased significantly with age. However, there was no correlation between CD4Tcell count and Parasitaemia in asymptomatic Plasmodium falciparum which could be as a result of the non severity of the asymptomatic malaria. Engelbrecht et $a l^{21}$ also found this in the results of study on the analysis of Plasmodium falciparum infection, there was no correlation between CD4
Tcell count and the multiplicity of the $P$. falciparum infections. The work of Simooye et al. ${ }^{22}$ is in agreement with these results they found no significant differences in antibody titres of $P$. falciparum in patients who were positive for HIV antibody and in those who were negative, whether or not they had Parasitaemia.

Interestingly, considering the mean age, CD4 Tcell count and parasitaemia of both males and females in the study, it is clearly seen that there was no significant difference, showing that both males and females had the same level of $P$. falciparum infection.

Grouping the patients used in the study into infants and children, youths and adults and comparing the infant and children mean values of CD4 Tcell count and parasitaemia of age groups 0-10 years against 11-20 years, 41-50 years, 51-60 years, above 60 years, no significant difference was found, there was no dis- similarity between the mean parasitaemia and CD4 Tcell count. With group 21-30 years and 31-40 years however, there were significant differences; the mean of age group 0-10 years was higher than that of 21-30 which was 319.19 cell for the CD4Tcell count and 2775.56 per $\mu \mathrm{L}$ of blood to 1617.14 per $\mu \mathrm{L}$ of blood for the parasitaemia. Engelbrecht et al. ${ }^{21}$ also made similar findings. The age distribution of the average number of parasite clones present in $P$. falciparum infections in their study, showed an initial increase, then reached peak multiplicity in children 8-10 years of age and afterward decreased significantly with age.

In conclusion, this study has shown that in asymptomatic Plasmodium falciparum infections in HIV positive patients, almost all the tested patient are positive for malaria infection compare with the low malaria infections in HIV negative patients (control), which could

Table 1. Showing sex number the mean age, parasitaemia and CD4t cells count of the positive samples.

\begin{tabular}{lcccc} 
Positive & N(\%) & $\begin{array}{c}\text { Mean age } \\
\text { (years) }\end{array}$ & $\begin{array}{c}\text { Mean parasitaemia } \\
(\mu L)\end{array}$ & $\begin{array}{c}\text { Mean CD4 T cells count } \\
(\text { cells } \mu L)\end{array}$ \\
Male & $35(33.8 \%)$ & $27.60 \pm 18.685$ & $1794.29 \pm 1114.7$ & $481.34 \pm 631.9$ \\
Female & $48(52.4 \%)$ & $31.25 \pm 13.315$ & $2055.83 \pm 2104.9$ & $433.25 \pm 245.5$ \\
Total & $83(86.2 \%)$ & $29.71 \pm 15.80$ & $1945.54 \pm 1752.57$ & $453.53 \pm 448.03$ \\
Control(Pos) male & $3(33.34)$ & $23.33 \pm 24.90$ & $120.00 \pm 40.00$ & $747.67 \pm 417.29$ \\
Control(Pos) female & $5(45.45)$ & $36.80 \pm 18.43$ & $128.00 \pm 95.49$ & $624.40 \pm 264.47$ \\
\hline
\end{tabular}

Table 2. Showing the general characteristics of the total positive samples using the age range.

\begin{tabular}{|c|c|c|c|c|c|}
\hline $\begin{array}{l}\text { Age range } \\
\text { (years) }\end{array}$ & $\begin{array}{l}\text { Number of } \\
\text { samples examined }\end{array}$ & $\begin{array}{l}\text { Number of } \\
\text { samples positive }\end{array}$ & $\begin{array}{l}\text { Mean age positive } \\
\text { (\%)(years) }\end{array}$ & $\begin{array}{l}\text { Ean parasitaemia } \\
\text { M Positive } \mu L(\%)\end{array}$ & $\begin{array}{c}\text { Mean CD4 T cell } \\
\text { count positive } \\
(\%)(\text { cell } / \mu \mathrm{L})\end{array}$ \\
\hline $0-10$ & 18 & 17 & $3.18 \pm 3.167(1.9 \%)$ & $\begin{array}{c}2938.82 \pm 3092.96 \\
30.9 \%\end{array}$ & $\begin{array}{c}807.24 \pm 778.14 \\
32.7 \%\end{array}$ \\
\hline $11-20$ & 1 & 1 & $16.00 \pm-(0.6 \%)$ & $160.00 \pm-0.1 \%$ & $381.00 \pm-0.9 \%$ \\
\hline $21-30$ & 21 & 20 & $\begin{array}{l}28.10 \pm 2.553 \\
\quad(19.6 \%)\end{array}$ & $\begin{array}{c}1698.00 \pm 952.76 \\
(21.0 \%)\end{array}$ & $\begin{array}{c}325.55 \pm 274.800 \\
(15.5 \%)\end{array}$ \\
\hline $31-40$ & 29 & 26 & $\begin{array}{l}35.42 \pm 2.671 \\
\quad(32.2 \%)\end{array}$ & $\begin{array}{l}1623.08 \pm 1151.39 \\
(26.1 \%)\end{array}$ & $\begin{array}{l}349.38 \pm 220.31 \\
(21.6 \%)\end{array}$ \\
\hline $41-50$ & 17 & 14 & $\begin{array}{c}45.29 \pm 2.585 \\
(22.2 \%)\end{array}$ & $\begin{array}{l}1862.86 \pm 1171.22 \\
(16.2 \%)\end{array}$ & $\begin{array}{c}354.64 \pm 147.18 \\
(11.8 \%)\end{array}$ \\
\hline $51-60$ & '4 & 4 & $54.50 \pm 3.32$ & $1880.0 \pm 1471.15$ & $456.25 \pm 396.98$ \\
\hline$>60$ & 3 & 1 & $61.00 \pm-100 \%$ & $1154.00 \pm-2.7 \%$ & \\
\hline
\end{tabular}

Table 3. Showing infection state using CD4 count group.

\begin{tabular}{|c|c|c|c|c|c|c|c|c|c|}
\hline \multirow[b]{2}{*}{ CD GRP } & \multicolumn{2}{|c|}{$\begin{array}{c}\text { Number of samples } \\
\text { examined }\end{array}$} & \multirow[b]{2}{*}{ Total } & \multicolumn{2}{|c|}{$\begin{array}{l}\text { Mean age } \\
\text { (years) }\end{array}$} & \multicolumn{2}{|c|}{$\begin{array}{l}\text { CD4 T count }(\text { cell/ } / \mu \mathrm{L}) \\
\text { (mean) }\end{array}$} & \multicolumn{2}{|c|}{$\begin{array}{l}\text { PARASITAEMIA } \\
\text { (mean) }(\mu \mathrm{L})\end{array}$} \\
\hline & Pos & Neg & & $\begin{array}{l}\text { Pos } \\
\text { samples }\end{array}$ & $\begin{array}{l}\text { Neg } \\
\text { samples }\end{array}$ & Pos & Neg & Pos & Neg \\
\hline$<350$ & 39 & 5 & $44(51.2 \%)$ & $\begin{array}{c}32.31 \pm 13.16 \\
\quad(44.0 \%)\end{array}$ & $\begin{array}{c}4.20 \pm 1492 \\
(7.2 \%)\end{array}$ & $\begin{array}{c}176.69 \pm 99.10 \\
(16.4 \%)\end{array}$ & $\begin{array}{c}2509.60 \pm 69.72 \\
(2.5 \%)\end{array}$ & $\begin{array}{c}1877.95 \pm 1123.64 \\
(45.4 \%)\end{array}$ & $\begin{array}{c}0.00 \pm 0.000 \\
(0.0 \%)\end{array}$ \\
\hline$>350$ & 44 & 5 & $\begin{array}{c}49 \\
48.8 \%\end{array}$ & $\begin{array}{l}27.41 \pm 17.65 \\
\quad 42.2 \%\end{array}$ & $\begin{array}{l}37.80 \pm 20.65 \\
\quad(6.6 \%)\end{array}$ & $\begin{array}{c}698.91 \pm 492.93 \\
(73.3 \%)\end{array}$ & $\begin{array}{c}656.40 \pm 134.69 \\
(7.8 \%)\end{array}$ & $\begin{array}{c}2005.45 \pm 2175.71 \\
\quad(54.6 \%)\end{array}$ & $\begin{array}{l}0.00 \pm 0.000 \\
(0.0 \%)\end{array}$ \\
\hline TOTAL & 93 & & $\begin{array}{c}93 \\
100\end{array}$ & $\begin{array}{l}30.76 \pm 16.136 \\
(100.0 \%)\end{array}$ & & $\begin{array}{c}451.32 \pm 430.553 \\
100.0 \%\end{array}$ & & $\begin{array}{c}1736.34 \pm 1762.05 \\
100 \%\end{array}$ & \\
\hline
\end{tabular}


be as a result of the depletion in the immune system. Parasitaemia has nothing to do with CD4 Tcells count, hence, cannot be a good parameter in the determination of asymptomatic $P$. falciparum infection in HIV patients. Age had impact on the CD4 T cells count and the level of Parasitaemia which should be noted when further work is to be done.

\section{Recommendations}

There is a need to always screen for malaria infection not only in symptomatic but also in asymptomatic patients. The most appropriate method for parasitic detection still remains the staining technique. For further work on the asymptomatic $P$. falciparum infection in HIV patients, gender discrimination should not be considered as there was no significant difference between males and females.

\section{References}

1. Snow RW, Guerra CA, Nor AM. The global distribution of clinical episodes of Plasmodium falciparum malaria. Nature 2005;434:214-7.

2. Molineaux L, Gramiccia G. The Garki project: research on the epidemiology and control of malaria in the Sudan Savanna of West Africa. World Health Organization ed. Geneva; 1980. pp 257-9.

3. Tinto H, Rwagacondo C, Karema C. In-vitro susceptibility of Plasmodium falciparum to monodesetly lamodiaquine, dihydrocritemsinin and quinine in an area of high chloroquine resistance in Rivanda. Trans R Soc Trop Med Hug 2005;100:509-14.
4. Centre for Disease Control. Chloroquine resistant Plasmodium falciparum malaria in West Africa. MMWR Morb Mortal Wkly Rep 1987;36:13-4.

5. Blacklock DB, Southwell T. A guide to human parasitology. 10 Ed. Southwell Press. London, 1990. pp 24-26.

6. Cogswell F. The hypnozoite and relapse in primate malaria. Clin microbiology Rev 1992;5:26-35.

7. Oniyangi 0, Omari AAA. Malaria chemonprophylaxis in sickle cell disease. Cochrane Database Syst Rev 2006: CD003489.

8. Trampuz A, Jereb M, Muzlovic I, Prabhu RM. Clinical review: severe malaria. Crit Care 2003;7:315-23.

9. Kain K, Harrington M, Tennyson S, Keystone J. Imported malaria: prospective analysis of problems in diagnosis and management. Clin Infect Dis 1998;27:1429.

10. Frensch N, Nakiyingi J, Lugada E, et al. Increasing rates of malaria fever with deteriorating immune status in HIV -1infected Ugandan adults. AIDS 2001;15: 899-906.

11. Antelman G, Msamanga GIU, Sieegelman $D$, et al. Nutritional factors and infectious disease contribute to anemia pregnant women with HIV in Tanzania. J Nutr 2000;130: 1950-7.

12. Owotade FJ, Adebiyi KE, Kehinde EA, Aboderin OA, et al. Is malaria a predisposing factor for third molar pericoronitis in the tropics? J Infect 2006,53:56-9.

13. Brentlinger PE, Behrens CB, Kublin JG. Challenges in the prevention, diagnoses, and treatment of malaria in human immunodeficiency virus infected adults in sub-Sahara Africa. Arch Intern Med 2007;167:1827-36.

14. Adetifa IM, Akinsulie AO, Temiye EO, et al.
Effect of antiretroviral therapy on asymptomatic malaria parasitaemia in HIV-1 Infected children. Niger postgrad Med J 2008;15:141-5.

15. Cheesbrough M. Medical Laboratory. Manual for Tropical countries. University press. Cambridge; 1992. pp 221-250.

16. Khasnis AA, Karnal DR. Human Immunodeficiency virus type 1 Infection in patients with severe falciparum malaria in Urban India. J Post Med 2003;49:114-7.

17. Van Greertruydean JP, Mulenga M. Chalwe $\mathrm{V}$, et al. Impact of HIV -1 Infection on the hematological recovery after clinical malaria. J Acquir Immune Defic Syndr 2009;50:200-5.

18. Kublin JG, Patnaik P. Jere CS, et al. Effect of Plasmodium falciparum malaria on cincetratum of HIV -1-RNA in the blood of adult in rural Malawi: a prospective cohort study. Lancet 2005;365:233-40.

19. Onyenekwe CC, Ukibe N, Meludu SC, et al. Prevalence of malaria as co-infection in HIV-infected individuals in a Malaria endemic area of southern Nigeria. J vector Borne Dis 2007;44:250-4.

20. Frensch N, Gilks CF. Royal Society of Tropical Medicine and Hygiene meeting at Manson House, London, 18 March 1999. Fresh from the field: some controversies in tropical medicine and hygiene. HIV and malaria, do they interact? Trans R Soc Trop Med Hyg 2000;94:233-7.

21. Engelbrecht F, Togel E, Bech HP, et al. Analysis of Plasmodium falciparum infection in a village community in Northern Nigeria. Acta tropica 2000;74:63-71.

22. Simooya 00, Mwendapole RM, Sizyya S, Fleming AF. Relation between falciparum malaria and HIV seropositivity in Ndola, Zambia. Biomed J 1988;297:30-1. 